\title{
Women, Islam and Cinema
}

\author{
By Latika Padgaonkar
}

Fall 2005 Issue of KINEMA

Gönül Dönmez-Colin's book, Women, Islam and Cinema, comes not a day too soon. At a time when controversies rage over the wearing of the veil in school, reality seems to be catching up with fiction. DönmezColin speaks of the insidious and conservative ways in which cinema in many Islamic countries has portrayed women. Her sweep is large: she covers India, Pakistan, Bangladesh, Malaysia, Indonesia, Iran, Turkey, Kazakhstan and Uzbekistan and draws careful analogies and contradictions that exist within and among these countries. Inevitably, cinema's depiction of women as actresses, directors and spectators grows out of the prevailing social and political atmosphere: stifling patriarchy and female subordination.

Women, Islam and Cinema is an exploration of Islamic society even as it is a comment on women's representation in cinema. Dönmez-Colin handles every social cliché that the Seventh Art has exploited: male dominance, suicide, polygamy, child marriage, the ferocious desire for a male child, custody of children in case of divorce, honour killings, dictates of dress and manner etc. - all the while pandering to the woman's body, first showing her in the nude, then condemning her as polluted. Either way - whether it is the image of the good suffering woman or of the naughty seductress that is on offer - cinema has done utter disservice to womanhood.

Behind this censorial attitude lurks a cunning sense of business. In Turkey, India, Pakistan and elsewhere, rural melodramas have striking commonalities: buxom village belles weighed down by make-up and decorated like Christmas trees moving amidst rustic bliss. These are nothing but simple profit-making options. Women's oppression would hardly go down well with a male audience. But a subjugated woman's tears could be a beautiful if transient moment.

Thankfully, there are also male directors who have taken up cudgels on women's behalf. They have dared to navigate the choppy waters of evil social custom and official censorship to create women who are strong and resilient individuals. Dariush Mehrjui and Jafar Panahi in Iran; Ömer Kavur and Atif Yilmaz in Turkey among others. Nor does Dönmez-Colin miss the paradox that "the most progressive films about women are made in Iran where sharia rules every aspect of life." The struggle to escape the sharia's fetters is often led by women directors themselves - Rakshan Bani Etemad, Tahmineh Milani and Marziyeh Meshkini - who have resorted to ruse, metaphor and sophistry to make their point.

Women, Islam and Cinema weaves Dönmez-Colin's personal peregrinations into her narrative: the interviews she conducted, the films she watched, and cinema's national histories which she studied. But this intelligent book and its no-nonsense style does leave you feeling a shade sad as you lay it down. While her introduction evokes the conflict between tradition and modernity and 'false modernity' in the early days of cinema, her conclusion tells you that such change as is visible today is small. In many countries, religion as a regulator of social and political life remains pivotal, and patriarchy is still very much in place.

\section{Author Information}

Latika PADGAONKAR is the executive editor of Cinemaya, The Asian Film Quarterly and a columnist writing on cinema and literature. She has served on several film festivals juries. She was a National Information Officer for UNESCO in New Delhi (15 years) and a foreign correspondent in Paris for the Indian daily The Telegraph. 


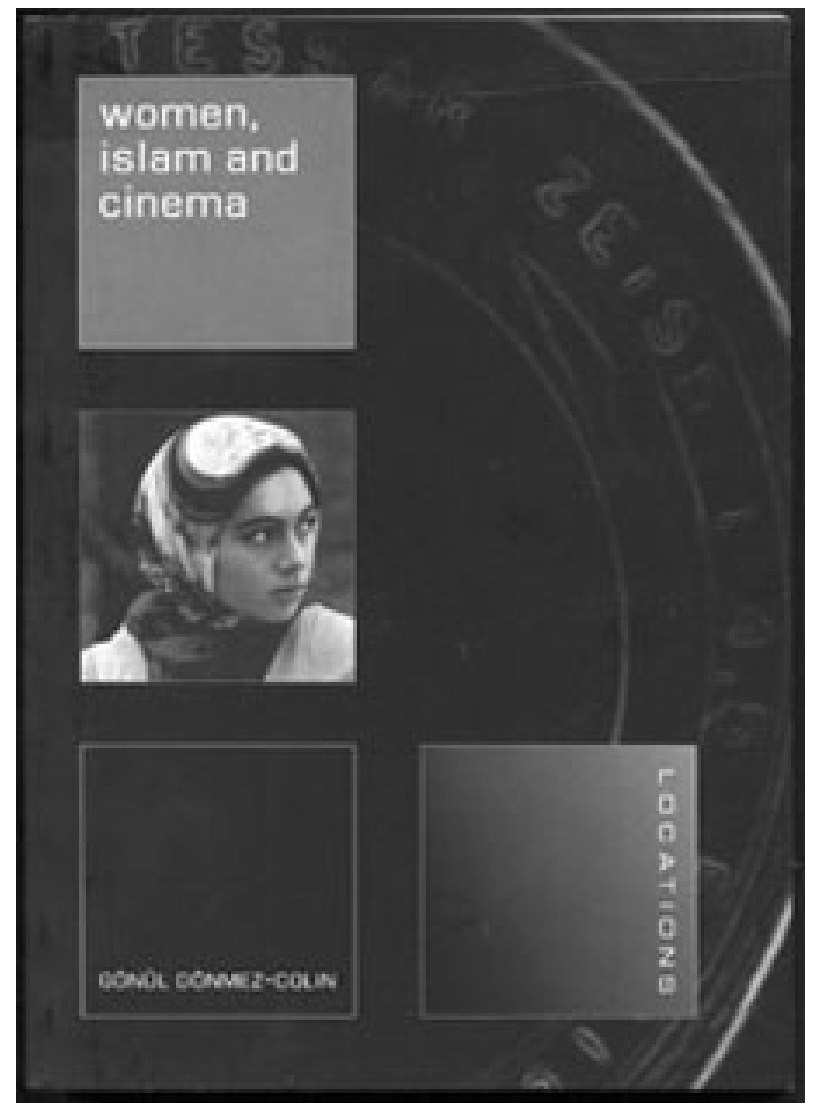

Figure 1: WOMEN, ISLAM AND CINEMA ๆ By: Gönül Dönmez-Colin ๆ London: Reaktion Books, 2004, 208pp. ๆ ISBN: 1861892209 (paperback) ๆ GBP 10.00 (list) 